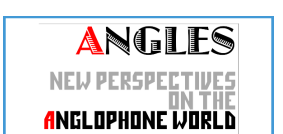

ANELOPHONE WORLI

\section{Angles}

New Perspectives on the Anglophone World

$13 \mid 2021$

The Torn Object

\title{
Murmur, Hum, Shout, Crash!
}

Listening, Suddenness and Passing Time with Beckett and Contemporary Installation and Video Art

Adrienne Janus

\section{CpenEdition}

12 Journals

\section{Electronic version}

URL: https://journals.openedition.org/angles/4797

DOI: $10.4000 /$ angles.4797

ISSN: 2274-2042

\section{Publisher}

Société des Anglicistes de l'Enseignement Supérieur

\section{Printed version}

Date of publication: 15 December 2021

\section{Electronic reference}

Adrienne Janus, "Murmur, Hum, Shout, Crash! ", Angles [Online], 13 | 2021, Online since 15 December 2021, connection on 21 January 2022. URL: http://journals.openedition.org/angles/4797 ; DOI: https:// doi.org/10.4000/angles.4797

This text was automatically generated on 21 January 2022.

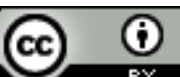

Angles est mise à disposition selon les termes de la Licence Creative Commons Attribution 4.0 International. 


\title{
Murmur, Hum, Shout, Crash!
}

\author{
Listening, Suddenness and Passing Time with Beckett and Contemporary \\ Installation and Video Art
}

\section{Adrienne Janus}

\section{Beckett and Experimentation}

1 Samuel Beckett's name so frequently appears as the 'last modernist' in the canonical triumvirate Yeats, Joyce, Beckett, that it's easy to forget that his works not only inspired, but are contemporary with, the waves of experimentation that emerged from the late 1960s. ${ }^{1}$ From the late 50s through the 80s, Beckett's name headlined the transatlantic avant-garde featured in the Evergreen Review. ${ }^{2}$ His texts, radio and television scripts appeared alongside Allen Ginsberg's "Howl" (1957) and Michael McClure's "The Growl" (1964), translations of Antonin Artaud's calls for a theatre of noises and cries (1958), and manifestos by media guru Marshall McLuhan, including "Innovation is Obsolete" (1971), a paean to the "new life born from garbage" in the hum of the first transatlantic satellite-relayed television transmissions that turned the whole earth into a multimedia installation environment. ${ }^{3}$ It's hard to miss the connection to Beckett's 35-second 'play' Breath, which first opened in Glasgow and New York in 1969, and combines the visual detritus of an assemblage of garbage with the "cry of the vagitus" and the electronically amplified guttural hum of inhalation and expiration (Beckett 1984: 211). By 1969, it seems, the innovative experimental temporalities and assemblages of Allan Kaprow's Happenings, with the discontinuous passage of sound and image aided by slide-projectors and loud-speakers, were already obsolete. $^{4}$

2 Beckett's post-war theatrical minimalism in plays like Breath is often connected to the performance and installation art of the late 60s onwards (Harari 2010; Reginio 2017). But his late work in television is where Beckett's entangled connections as both predecessor and contemporary of avant-garde experimentation come to the fore. Beckett's 1953 novel Watt inspired the vertiginous instability of the gravity-burdened 
pacing of Bruce Nauman's closed-space performance piece Slow Angle (Beckett Walk) (1968) (Figure 1). ${ }^{5}$

Figure 1. Bruce Nauman, Slow Angle (Beckett Walk) (1968) video [still image]

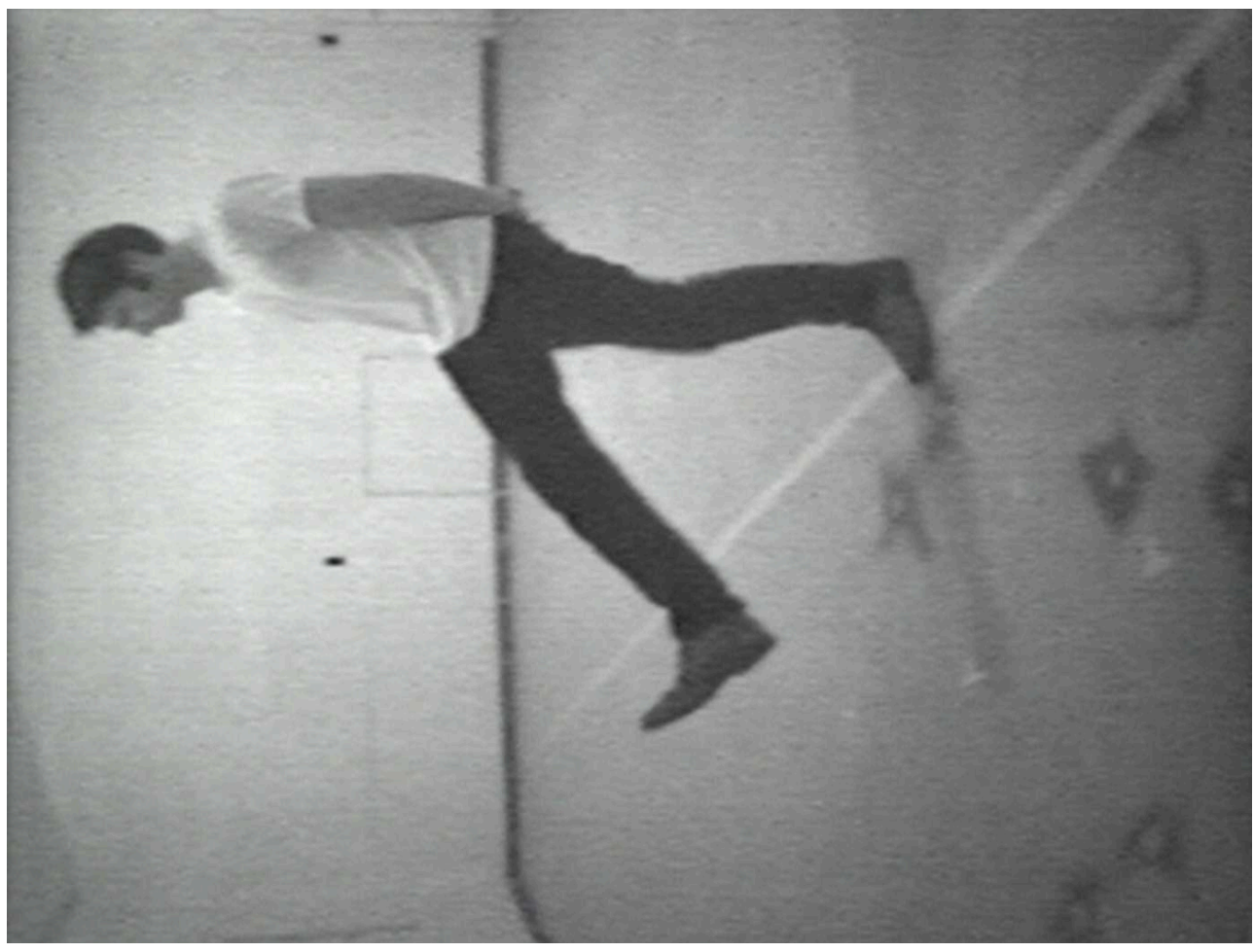

Credits: Smithsonian American Art Museum, https://americanart.si.edu/artwork/slow-angle-walkbeckett-walk-77198

This appeared the same year as Richard Serra's Hand Catching Lead (1968), involving the repeated passage of an ungraspable, indistinct blurry object falling and crashing silently to the ground.

This media file cannot be displayed. Please refer to the online document http:// journals.openedition.org/angles/4797

At the same time as Serra, Nauman and others were experimenting with the possibilities of short-film, television and video, Beckett was also busy engaging in his own closed-spaced video and television experiments, with the Film Vidéo-Cassette projet of $1968--72$ informing television works for BBC 2 and Suddeustcher Rundfunk. ${ }^{6}$ These include Eh Joe (1966), Ghost Trio (1975), and ...but the clouds (1977), featuring solitary figures shuffling through their ritual paces in enclosures where they are subjected to the transmissions of indistinct, murmuring voices, and a televised version of the play Not I (1977), with its close-up image of a mouth issuing its continuously 'buzzing' monologue of almost inarticulate murmurs punctuated by sudden screams and silence. ${ }^{7}$ Finally, as though in homage to Nauman, and testimony to the speedy obsolescence of analogue television itself, Beckett's last work for television, Quad (BBC 2 1982) features the blurred passage - both sudden and impossibly slow - of four gravity-burdened bodies, barely avoiding the anticipated crash of contact in the central “danger zone" (Beckett 1984: 293). 
This brief and incomplete résumé not only calls attention to how Beckett's long career both inspired and fused with waves of experimentation across various media in ways that challenge conventional periodising narratives. It also foregrounds the way particular aesthetic features - indexed by the 'murmur, hum, shout, crash' of my title - have accompanied these waves of experimentation across various media. The appearance of these features in Beckett's late oeuvre, as in other contemporary experimental works, are not merely sound effects. They are, in the first case, fundamental material in the armoury of techniques used to attack traditional aesthetic certainties and audience expectations associated with object-centred notions of medium specificity, including the idea of the work of art as a distinct, graspable object of exposition or interpretation. They are also, I will argue, indexical markers of modes of appearing ${ }^{8}$ particular to the experimental temporalities of the $20^{\text {th }}$ and $21^{\text {st }}$ century avant-garde, neither of them graspable as a coherent teleology or objective whole: murmurs and hum marking the indistinct passage of a continually unfolding passage of time; shouts and crashes, marking the momentary, sudden, inexplicable eruption of an event.

\section{Murmur, hum, shout, crash: Arms in the avant-garde challenge to object-centred notions of medium specificity}

One of the themes of Beckett's long career has been the desire to tear apart the symbolic unities of the work of art as a distinct, graspable object of interpretation. From his earliest call to "tear apart the terrible materiality of the word surface" in a "literature of the unword," (Beckett 1984: 172) to drama as a theatrical "happening" where, as Vivian Mercier famously said of Godot, "nothing happens... twice" (1977: 74), Beckett searched for ways to pervert the capacities normally granted to each artistic medium he worked in, taking particular pleasure in rendering the apparent powers of 'new' media technology obsolete. ${ }^{9}$ In experimental radio plays such as All That Fall (1957), Embers (1959), Words and Music (1962), Beckett uses the indistinct materiality of murmuring voices, shuffling feet and tempests of wind and rain to dissolve words and music - the primary auditory objects of the radio medium - into indistinct radio static white noise silence. The flickering black and white, almost silent Film (1965) foregrounds the horrors of visual perception. It stars the stumbling, blinking Buster Keaton trying to escape the camera's gaze and resist becoming the visual "object of simultaneous collective experience" that Benjamin declared to be the cinematic medium's privileged mode of audience address (Benjamin 1968a: 240). Then on to television, with Eh Joe (1966), Ghost Trio (1975), and ...but the clouds (1977). These works not only use a "new form of inclusive disjunction" of word, image and sound described by Deleuze in the afterword to the print edition of Beckett's television works - like playing a radio transmission and a silent film in dissonant counterpoint (Deleuze 1992). They also counter the long-distance optical address of television and its capacity to 'monitor' or fix far away events in view (Cavell 1982), by featuring close-ups of solitary, listening figures subject to murmuring voices and spectral, ungraspable audio-visual presences that emerge and disappear of their own accord.

7 It is such challenges to object-centred orthodoxies of medium-specificity - the supposed opticality of visual media, the aurality of sound-media, the 'literariness' of 
texts, not to mention the hermeneutics of language as a medium of discursive communication - that lead us away from artistic and critical practices wedded to distinctions between the various media of literature, painting, photography, theatre, and film as discrete objects of exhibition or analysis towards critical and artistic practices associated with the heterogeneous, indistinct multiplicity of what Rosalind Krauss calls the 'post-medium' condition that characterises late $20^{\text {th }}$ century and early $21^{\text {st }}$ century multi-media installation and video performance art. Television and video, Krauss argues, despite being a distinct technical apparatus, offered artists such as Serra and Nauman the capacity of use words, images, and sounds to produce a "heterogeneity of activities without a unifying core," and to include "diverse forms, spaces and temporalities" in one work (Krauss 1999: 31$).{ }^{10}$ As such, experiments with television and video by avant-garde artists such as Serra, Nauman, and, I'll argue, Beckett, play a particular role in the development of $21^{\text {st }}$ century multi-media installation and video performance art. However, theorists such as Krauss and Deleuze, as well as critics of Beckett's television plays, leave important questions unanswered: given the end of object-centred, medium specific modes of address - of looking at visual images, listening to sounds, and reading words - what features, mode of audience address or aesthetic disposition does the new heterogeneity of diverse forms, spaces and temporalities imply?

8 On the way to answering these questions, I'd like to explore 'murmur, hum, shout, crash' as material markers of particular aesthetic forms and temporalities fundamental to the development of the 'post-medium' condition of $21^{\text {st }}$ century multi-media installation and video performance art. While touching upon a variety of works that exist across the media of live performance, literary texts, audio-tape, video and film (Michael McClure's Ghost Tantras, Alan Kaprow's Happenings), ${ }^{11}$ I'm most interested in the ways Beckett's work in technological media, his late television works in particular, bring to the foreground these features also fundamental to $21^{\text {st }}$ multi-media installation and video performance art. I'll focus on situating Beckett's late television works in relation to the multi-media installation and video performance work of some $20^{\text {th }}$ and $21^{\text {st }}$-century artists who are both explicitly and implicitly affiliated with Beckett. These include celebrated, older artists such as Bruce Nauman, whose early work directly cites Beckett as inspiration, and whose recent installation, Raw Materials (Tate Modern, 2004), foregrounds the murmur, hums, shouts, and crashes that have served as the artist's raw materials throughout his career. As a nod to the diversity of experimentation that has found a home outside of the cosmopolitan centres of experimentation (London, Paris, New York) ${ }_{1}^{12}$ I'll also attend to younger, lesser-known artists from what might be called the 'provincial' avant-garde of the British Isles: Northern Irish and Scottish artists John d'Arcy and Cathie Boyd, whose Beckett Basement, an installation of words, sound and images in the basement of historic Castle Coole, premiered at the Beckett centenary festival in Enniskillen in 2011, and uses Beckett's own works as the raw materials to create the basal humming resonance that accompanies our passage through the space, ${ }^{13}$ and Bristol-based duo Paul Harrison and John Wood, whose video performances featuring the gravitational play of bodies that hover in suspension or fall and crash recall both Nauman and Beckett's closed-space video and television works of the late 60s. Their work has been frequently featured at the Tate, and their recent collection, Unrelated Incidents, premiered at the Gallery West in the Hague in 2012 (Janus 2012b). 
9 In setting up this particular line-up of artists, it is not my intention to map out a new genealogy of artistic experimentation that runs from Beckett through the $21^{\text {st }}$ century. Rather, I'm more interested in the ways that, despite their apparent heterogeneity, these works each transpose through their diverse forms and spaces common features: namely, ephemeral, ungraspable audio-visual phenomena associated with 'murmur, hum, shout, crash.' These phenomena serve as material, indexical markers of experimental temporalities, perceptual experiences and modes of audience address which are fundamental to contemporary artistic practice. The first has to do with the lingering resonance of a continuously passing audio-visual movement - the indistinct murmuring, organic or mechanical rustling, humming, flickering and shimmering. The perceptual disorientation produced by these features - the loss of spatio-temporal points of reference, where we are asked to listen without localising, and look without being able to fix a point of view - implies a disposition or mode of audience address that, while by no means being reducible to auditory perception, can be more fittingly described as a mode of immersive listening than of looking and its associated optical paradigms. The second has to do with the sudden, inexplicable emergence and disappearance of an audio-visual presence - the shouts, crashes and flashes and other evanescent, momentary events, associated as much with the Benjaminian shock of modernity as with the instantaneity of technological transmission of contemporary multimedia installation and video art, where we are subject to - or hit - by the attack of another, indistinct, ungraspable presence.

These features - the murmur, hum, shout, crash announced by my title, and other associated phenomena - may seem to have emerged suddenly on scene with the postwar avant-garde. But they have been latent properties of modernist and protomodernist works of art across various media, moving increasingly into the foreground with the rapid pace of change of the modern age, and the material, technological and conceptual challenges to the stability of objective frames of reference in both art and history. In the following discussion, and in selected excerpts of the works in question, I separate these phenomena according to their two modes of temporal appearing passing away and suddenness - in order to better highlight the conceptual and perceptual differences between them in ways that the full experience of our encounters with the works don't easily allow.

\section{Murmuring, Humming, Shimmering, Passing Away}

11 Let's turn now to the first mode of appearing indexed by murmur and hum. This has to do with the irretrievable passage of a continuously unfolding audio-visual movement whose emergence and disappearance are too fleeting to attend to as a graspable object of perception - the indistinct murmuring of voices, the rustling or humming of organic or mechanical white noise, the shimmering or flickering of light, the blur of bodies in motion. In the age before mechanical reproduction, such phenomena frequently appeared as a background, atmospheric feature of works of art across various media. Yet even these early instances attract critical attention due to the particular aesthetic disposition and modes of audience address occasioned: perceptual disorientation, loss of objective reference points, immersion in the "enduring passing away" of appearances (Seel 2005: 147). Take, for example, Wagner's multi-media Gesammtkunstwerke - the 'glittering shimmer' of the Rhein waters, the famous 'rustling' 
oscillations of orchestral strings in Siegfried's 'Forest Murmurs,' the special effects of steam and light. The atmospheric effects produced by the continuously unfolding passage of such acoustic and visual resonating inspires Nietszche's formulation of Dionysian 'intoxication' in The Birth of Tragedy, the perceptual rolling and tumbling of immersion in something that cannot be grasped as a determinable object or form. Nietzsche's attention to such phenomena is, according to Martin Seel, "the beginning of the theoretical recognition of a phenomenon without which contemporary aesthetic practice would be unthinkable" (141).

Following Nietzsche, Adorno too recognizes such phenomena, in a radio address in 1957, incidentally the same year as Beckett's first radio play, All that Fall, where he describes the continuous passing away of temporal forms that appear as "the rushing, rustling, murmuring sound of nature [...] living on only in the process of dying away" as "a residue of uncontained Romanticism that leads to the threshold of modernity" (Adorno 1991: 65). While Adorno addresses his attention to the rustling, murmuring of lyric poetry, the aesthetic disposition he describes, that of enticing the audience to "listen without localising" and to lose oneself in the "back and forth movement" of the incessant emergence and disappearance of its passage, applies even more to the perceptual experiences of art produced by electronic media (Adorno 1991: 64). It appears in the fusion of the organic and mechanical murmuring in Barthes' Le bruissement de la langue, and his praise of the intoxicating perceptions inspired by the out- of-phase murmuring of a multiplicity of children's voices in a film by Antonioni (Barthes 1984). The aesthetic disposition of this feature, when filtered through linguistic material and the poetics of sound, is described by Adorno as listening without localising. When materialised in visual images, the aesthetic disposition implied by such phenomena can be described as looking without identifying an object upon which to fix a point of view. ${ }^{14}$

13 In the post-war period, both the technical capacities of media and the historical mood - of time passing while the ability to index historical progress appears at a standstill push this mode of appearing and its associated phenomena to the fore. Of course, what Adorno in his 1957 radio address identified as the enduring passing away of indistinct presences that "live on only in the process of dying away," has particular resonance in both the Irish and post-World War II context, as famously invoked by the "rustling, murmur" of "all the dead voices" in Beckett's Waiting for Godot. While Beckett's experiments with radio in All that Fall and Embers allow us to 'listen without localising' to the murmur of wind and rain, and the rushing, hum of sea-waves that emerge and disappear, the medium of television allowed Beckett to actualise in both sound and image those "forms fading among fading forms" of the passage of "time that is over and still goes on," first announced in the post-war novel Molloy (Beckett 1950: 17, 35).

In television works like Ghost Trio, the emergence and disappearance of these fading forms of a time that is over and still goes on is materialised by spectral audio-visual presences that emerge and withdraw out of a spatio-temporal void of silence and its visual equivalent - the flattening, pixelated, shimmering greyscale of the television screen. While Beckett's televisual experiments in this way work against the normative, 'objective,' properties of the television medium to 'fix' events in view, ${ }^{15}$ the closedspace settings and claustrophilic frame of the television monitor provide a framing space that mark such fleeting, spectral presences as worthy of close-attention, and 
speak to the impossible desire to contain and hold onto presences of the past in their continuous passage. ${ }^{16}$

The impossible desire to contain and hold onto presences of the past in their continuous passage is also instantiated in contemporary works by John D'Arcy and Cathie Boyd's Beckett Basement, an installation in Castle Coole, and by Bruce Nauman's Raw Materials, an installation in London's Turbine Hall of the Tate Modern. These spaces are both haunted by enduring presences of the past, of colonial Ireland and England's industrial past respectively. Both installations use the technology inaugurated in the late 60s, by process artists such as Steve Reich, of looping out of phase audio recordings, to create a kind of continuously unfolding basal humming or machine murmuring that forms the continuously shifting acoustic ground accompanying our passage through the space of the installation. In addition to the presence of the past contained by the physical structures of buildings themselves, the out of phase audio recordings of both installations make use of material drawn from the past work of the artists in question (Beckett and Nauman). But these two works present different perceptual experiences, suggesting a different relation to the presences of the past. Beckett Basement emphasizes the perception of an enduring passing away, the continuous emergence and disappearance of presences of the past living on only in the process of dying away, the heterogeneity of the installation contained by the multiple passages through the rooms of the castle's structure. Nauman's installation runs through one long ( 152 metre) passage through the vast tunnel-like structure of the turbine hall. Nauman's out of phase sound-loops echoes within the vast hall to emphasize the chaotic heterogeneity and disorientation of immersion in a multiplicity of past presences, materialised by 18 different speakers spaced throughout the hall, transmitting 18 different sounds in a continuously repeated loop, heard distinctly only if you stand still.

Finally, Harrison and Wood's video performance works, Unrelated Incidents, address both in the framing of the video medium, and in their closed-room settings, the relationship between what Hans Ulrich Gumbrecht has called our present, post-war, modernity's desire for "containing, insulating forms," and the fascination with situations of derailment, with the continuous passage of "movements that escape control" (Gumbrecht 2013: 112). Harrison and Wood's video performances stage, and produce in our encounter with them, a kind of Beckettian circus-act version of the perceptual rolling, tumbling associated with Nietzschean intoxication.

I'd like to attend more closely to some excerpts which foreground the murmuring, rustling, humming enduring passing away of presences of the past in the works mentioned. The first, Beckett's Ghost Trio, presents us with a solitary figure enclosed within a rectangular space, a structural double of a sounding box and/or television monitor, crouched over a rectangular box, the structural double of a mechanical taperecorder. The features of both the human and mechanical forms are indistinct. As the filming directions note, the figure's "face [is] hidden, clutching with both hands a small cassette not identifiable as such at this range" (Beckett 1984: 249). The figure appears to be waiting, listening in attendance for the emergence of some possible audio-visual presence out of the silence and emptiness in which he is enclosed. This disposition of waiting attendance releases us (and the listening figure) from a temporal horizon that could be indexed to teleological structures of representation, or to the agency of a subjective consciousness, as we have no knowledge or control over when or what will 
appear. The first presence that appears, after an almost interminable 10-second silence, is the faint mechanical murmuring of an off-screen voice, a radio-transmission from a past age, "Mine is a faint voice. Kindly Tune accordingly." As we listen without being able to localise the source of the faint sound of the voice, it directs our attention to look without fixing a point of view towards "the Light: faint, omnipresent. No visible source. As if all luminous." (1984: 248) This murmuring voice emerges and disappears in the first two parts of the work to direct our attention to other spectral presences, before fading out entirely in the third and final part of the work. The most substantial and recurring of these spectral presences from the past, one that we and the listener await in an anxiety of expectation, and whose disappearance we mourn as it passes away, is that of the sound of Beethoven's piano trio op. 70 no. 1 called 'The Ghost.'

This media file cannot be displayed. Please refer to the online document http:// journals.openedition.org/angles/4797

Each time the music emerges, it reaches out to touch us from another world, an Adornian 'residue of Romanticism' materialised in the enduring passing away of a sonorous presence from the past, that for the duration of its playing, releases us from our containment in the silent, empty void of the visual image, and opens up a passage to another world into whose unfolding resonance and haunting beauty we lose ourselves. The sensual tactility of the mode of address implied by this sonorous spectral presence of the past, and its relation to the visual images, will be discussed in more detail later

For now, let's briefly turn to another residue of romanticism that appears only once in Ghost Trio, in the singular appearance of "the rushing, rustling, murmuring sound of nature [...] living on only in the process of dying away." This is in the final part of the play, when the window that had opened to nothingness and silence in the first two segments inexplicably opens, with a sudden creak, to the rushing passage of falling rain. It is brief, but strikes us with a fullness and plenitude in relation to the empty nothingness that surrounds it.

This media file cannot be displayed. Please refer to the online document http:// journals.openedition.org/angles/4797

The multiplicity of the individual changing forms of rain drops, and the continuous unfolding audio-visual movement as the rain rushes down, are too indistinct for conscious perception to individuate as they continually pass away. It is a comforting kind of white noise (the organic double of mechanical audio-visual static) producing a perceptual blurring that for the duration of its appearance allows us to lose ourselves, and releases us from the disposition of trying to master the meaning of events. We don't know why, nor does it matter why, it has begun to rain, and there is no interest in asking such hermeneutically directed questions such as 'What does this mean'? We would like to linger, to lose ourselves, in the enduring passing away of this audio-visual presence. But again, Beckett doesn't allow us to linger long; the pleasure of selfsurrender is cut off, with the creaking window as it closes, and we return to our confinement in the space of the present, enclosed and closed off from the rushing, rustling murmurs of the natural world, soon also only to be a presence of the past. 
21 Next, we come to Beckett Basement, and to how the 'hum' that is a particular feature of this work produces the perception of an enduring passing away. Our passage through the installation is accompanied by a continuous, unfolding of resonance, a continuity based on the continued basal resonance created by the murmuring of rain, of indistinct voices, and by a kind of low-frequency humming or rattling that can be heard throughout the passage, a kind of 'bruit de fond' or fundamental white noise out of which, and into which, indistinct spectral audio-visual presences continually emerge and disappear. Here is a brief clip, from a film of the installation by Jonathan Frazer. While lacking the immersive experience of the installation itself, the film orients us in pointed ways towards the disorientation of encountering these indistinct presences of the past.

This media file cannot be displayed. Please refer to the online document http:// journals.openedition.org/angles/4797

As we enter the installation, the enduring passing away of presences of the past emerges in the continually fading forms of spectral images, shimmering and fading as they pass. The camera directs us to look without being able to fix a point of view at these indistinct images, that, even as they materialise to take on textured solidity, as in the film version's close-up of the textured stone wall, produce a perceptual blurring, as those features that usually form the indistinct, atmospheric background of appearances move to the foreground, while maintaining their indistinct, material quality as background. Throughout our passage, we listen without localising to the continuous unfolding of resonance in that indistinct murmuring of rain, low-frequency rattling, then the murmuring of indistinct voices that traces time as pure passage, without distinct temporal markers. As we enter one room, a distinct human voice emerges to perception out of this continuously unfolding of indistinct resonance: a citation from Beckett's Molloy in a recording by Patrick Magee, one of Beckett's favourite actors - but the sound of this voice also resonates at the lower frequencies, creating the effect of another unfolding of resonance on top of the indistinct basal resonance out of which it appears. The resonance of this voice, too, though distinct in the articulation of the passage of language, is layered by an echoic after-effect, smoothing the silences between words, so that resonance endures even as words pass away. The passage from Beckett's Molloy runs as follows: "I, when I stayed still, was fixed too and when I moved from place to place, it was very slowly, as in a cage out of time, and out of space too." The passage is obviously well-chosen, as it reflects the idea of fixing presences in space, attempting to preserve them from the passage of time in an echoic enclosure in which we can immerse ourselves, where we can become one with these ephemeral presences of the past, however indistinct they may be.

As in Beckett's Basement, Nauman's installation makes use of a low-frequency resonance - a kind of basal humming or machine murmuring - as the unstable acoustic ground of the passage through the space of the turbine hall. This humming, murmuring basal resonance accompanying our passage though the hall is produced by the fusion of continuously looping fragments of raw material from Nauman's own career (audio tracts from past videos, installations, and texts) issuing from 18 different loudspeakers. As much as we might want to identify the origin of the works and orient ourselves in relation to a stable historical point of reference, through certain stretches of the passage, the constantly shifting emergence and disappearance of these past presences 
merges into an indistinct, continuously unfolding fusion of organic and mechanical murmuring - a barthesian bruissement - where we listen without localising and look without fixing a point of view (see at 2'25").

This media file cannot be displayed. Please refer to the online document http:// journals.openedition.org/angles/4797

This is, perhaps, one of the few stretches of the passage that dispose us to relax, let go and immerse ourselves in the intoxicating, enduring passing away of presence. More often, our movement through this space is marked by sudden shouts and disruptive attacks of sonorous presence that, as we shall discuss later, seem to reproduce the shock experience of industrial modernity.

Harrison and Wood's video performances, unlike the previous works we encountered, do not attest to a desire to contain and preserve the vestigial, material trace of past presences in their enduring passing away. Rather, they present us with a purely formal exploration of what Gumbrecht calls modernity's relationship between the desire for "containing, insulating forms," and fascination with situations of derailment, with "movements that escape control" (Gumbrecht 2013: 112). This is instantiated not only by their closed-room settings and the frame of video medium, but also by their experimentation with the formal, material properties of elaborately constructed devices, and nonrepresentational, geometric forms whose delicate equilibrium, in the minutely choreographed situations into which they often insert their own bodily forms, always risks derailment. These works are usually presented in a series, so the experience of passing time with these in the space of a museum or gallery has a cumulative effect, one of happy confusion and mildly disorienting intoxication as we lose ourselves in the continuously unfolding play of forms whose changes become too indistinct to fix and hold onto as a singular, graspable object.

first excerpt, from a series entitled Device (1996), involves the artists' play with modernity's desire for containing, insulating forms that always risks derailment.

This media file cannot be displayed. Please refer to the online document http:// journals.openedition.org/angles/4797

This excerpt is one of many in which the artists subject themselves, along with us, to a comically literal embodiment of the perceptual rolling and tumbling and vertiginous disorientation of modernity invoked by Nietzsche.

The second excerpt, from a series entitled, Night and Day (2009), invokes modernity's desire for containment in the first scene, in which the artists briefly appear with the subtitle, "they could hardly contain themselves." The scene then changes to reveal movements that escape control and temporal change itself is materialised in the blur of rapidly changing forms flickering between visibility and invisibility, presence and absence.

This media file cannot be displayed. Please refer to the online document http:// journals.openedition.org/angles/4797

9 We can encounter these scenes as a pure playing with the materiality of forms, and experience the mildly disorienting sensation of looking without being able to fix a 
stable, objective point of view. This is occasioned by our encounter with the enduring passing away of the flickering of light, and the continuous unfolding of an audio-visual movement in which a multiplicity of individual changing forms appears too indistinct for conscious perception to individuate as they continually fall and pass away (as in the rain of confetti). These scenes can also be said to index the disorientation of the rapid change of modernity that Benjamin saw captured in cinema's moving images, the continuous change of place and focus, where "No sooner has [our] eye grasped a scene than it is already changed" (Benjamin 1968a: 238).

This final excerpt is from a series entitled Notebook. This excerpt can be said to stage in comic miniature form mechanical modernity's rapid pace of change, no longer moving incessantly forward in constant progress, but turning about itself, contained briefly on its circular track, before derailing in a rush of movement that escapes control.

This media file cannot be displayed. Please refer to the online document http:// journals.openedition.org/angles/4797

We can anticipate - we know from reasoned experience - that equilibrium will be destabilised and things will fall. But the brief resonance of the fall - the decay of time with the acceleration of gravity, at a speed of 9.8 metres per second squared - is a passing away that occurs too quickly to hold on to, and we experience the vertiginous sense of falling along with the motion, until that satisfying 'thunk,' when the train hits the ground. Once again, we may experience this scene as the pure aesthetic play of forms of appearance, where the incessant motion of created forms suddenly changes direction, transforms into a blur of dissolving form, before coming to a rest. Or we can draw on our own conceptual store of past knowledge, and say that the train of modernity no longer accelerates into the future, but, subject to the acceleration of earth's incessantly moving mass, is yet merely another gravity-bound body that falls to the ground with a 'crash.'

\section{Flash, Shout, Crash}

This brings us to the second mode of temporal appearing: the sudden, inexplicable emergence and disappearance of an audio-visual-kinaesthetic presence, marked by shouts, crashes and flashes and other momentary events of audio-visual 'noise. ${ }^{17}$ The temporality of suddenness has long been associated with artistic experimentation, from the Romantic to the modernist literary arts (Bohrer 1994). With technological modernity, however, the embodied materiality of these momentary events moves to the foreground of appearance and serves as a productive disruptor to previously stable frames of reference. This mode of appearing not only works to index disruption to objective frames of historical reference, as the 'flash' that Benjamin describes erupting to "blast open the continuum of history" and allow an image of the past to emerge momentarily to presence (Benjamin 1968b: 255). The aleatory instantaneity of its happening and the material impact of its associated features also serve avant-garde and experimental artists to disrupt the containing boundaries of previously fixed aesthetic forms, traditional modes of representation, fields of discourse and modes of audience address. 
If the explosive energies of early avant-garde assaults on traditional literary and musical forms - from the car crash that launched Marinetti's Futurist Manifesto (1909) and Luigi Russolo's mechanical scream-machine Ululatori (1913), to Wyndham Lewis' Vorticist 'Blast'(1914) - dissipate with the destruction of World War I, as Marjorie Perloff's The Futurist Moment argues, they re-emerge, transposed in the inter-war period, with the new techniques and modes of audience address of mass media. The capacity of gramophone, radio, and film to record indiscriminately what was within range not only "shifted the boundaries that distinguished noise from meaningful sounds, random visual data from meaningful pictures sequences," as Friedrich Kittler theorises (1999: xxvi). The new mechanical ability to record the material qualities of appearances foregrounds their contingent opacity - what Mary-Anne Doane, in The Emergence of Cinematic Time, calls the 'thisness' of an event (2002: 65). This contingent, material opacity of the recorded content combined with the spectral, ghostly quality of instantaneous technological production and transmission, where sounds or images suddenly emerged and disappeared out of nothingness from gramophones, radio, or the cinematic screen. This contributed to the constitution of a new mode of audience address associated with an evanescent audio-visual tactility, the transmission of embodied affective vibrations. When Artaud sought, in the manifestos introduced to an Anglophone audience in the 1960s by the Evergreen Review, to use "sounds, noises, cries [...] for their vibratory quality" (Artaud 1958) to break theatre's traditional forms of speech-based, discursive address, and to treat the audience as though they were snakes - resonant bodies capable of being touched by affective vibrations across the whole of their core as they encounter any material support or medium - his tactics involve a turn to new media, first to silent-cinema to "clear a space for the unarticulated sounds whose production would follow later" (Hollier 1997: 29), then to radio, to transmit the embodied, feminized screams that punctuate Pour en finir avec le jugement de Dieu (1947). As Douglas Kahn has argued in his suggestively titled book, Noise, Water, Meat (1999), the embodied, affective energies of the Artauldian scream are picked up, transposed by the performative, experimental poetics of the post-war Anglophone world in the 1950s and 60 s, fuelling the counter-cultural energies of, for example, Allen Ginsberg's "Howl" as well as the glossollalic growls of Michael McClure's beast language. ${ }^{18}$ Here is a brief excerpt from McClure's Ghost Tantras (1962), a collection of poems recorded in part on audio-tape and film while the poet read to lions at the zoo:

We are served by machines making satins of sounds.

Each blot of sound is a bud or a stahr.

Body eats bouquets of the ear's vista.

Gahhhrrr boody eers noze eyes deem thou.

$\mathrm{NOH}$. NAH-OHH

hrooor. VOOOR-NAH! GAHROOOOO ME.

Nah droooooh seerch. NAH THEE!

The machines are too dull when we

are lion-poems that move \& breathe.

Here, it is as though the spectral, audio-visual tactility and opaque, material, 'thisness' of mechanical media is transfused back through the materiality of language. The sudden eruption of the mammalian vocalisation appears, like the Benjaminian flash, to arrest the continuum of history, so that "The touch of velvet on fingertips may become a cry when time is stopped," as Mcclure muses in his prefatory remarks to the work (Kahn 2003: 343). 

mediality of poetic language, in metabolising through the materiality of language the audio-visual tactile modes of address of mechanical media to communicate their sudden, disruptive, material energies. Yet in the context of the post-war period, any multi-media assault on traditional modes of theatrical performance would also have to work to disrupt the modes of audience address and aesthetic disposition of immersion in the totalising, totalitarian effects associated with the technological afterlives of Wagnerian-style fusions of words, image and sound. Thus Alan Kaprow's live Happenings would make use of the sudden materialisation of resonant bodies crashing together, loudspeakers and record-players emitting non-discursive vocalisations or fragments of music of their own accord, spectral images projected on walls and people, to create an environment where spectators become participants in the production of the chaotic heterogeneity of activities and events. As Kaprow describes one happening in a New York loft in 1961:

A hundred iron barrels swing back and forth, crashing like church bells. [...]. Suddenly, mushy shapes pop up from the floor [...] Words rumble past, whispering, dee-daaa, baroom, love me, love me; shadows joggle on screens; power saws and lawn mowers screech... Long silences when nothing happens [...] when bang! There you are facing yourself in a mirror jammed at you. Listen. (Kaprow 1993: 15)

Experiencing the sudden, inexplicable emergence and disappearance of such events, when filtered through Kaprow's descriptive language, which also choreographs audience directives to look and listen at the right moments, may be more compelling than the live happening itself. The extremity of the disruption between the boundaries between art and life, and the intensity of the live audio-visual and kinaesthetic impact upon participating audience members, often caused them to leave crying in shock. Kaprow may have effectively disrupted the teleological structures of both literarybased dramatic performance and Wagnerian spectacle, achieving the aims announced when he insists that, "Happenings are events that, put simply, happen. Though the best of them have a decided impact - that is, we feel, 'here is something important' - they appear to go nowhere and do not make any particular literary point" (Kaprow 1993:16). Yet happenings as live-performance events were too ephemeral and unrepeatable to make a lasting impact on a wide audience.

It is this historical and artistic context, in the late 60 s and early 70s, that sets the stage for the emergence on scene of television and the video porta-pack, not as a medium of popular entertainment, but as a broadcast medium for otherwise ephemeral artistic events, one that allowed both the choreographed framing distance and the preserving, repeatable record of sudden, disruptive modes of appearing that Kaprow's Happenings lacked. Television, moreover, despite the apparent merely 'optical' address of televisual images, was perceived as a medium capable of enacting the audio-video-tactile and kinaesthetic mode of address that experimental artists like Artaud had sought in earlier tactical turns towards new media technologies. Thus, Marshall McLuhan, in Understanding Media, his celebrated tome on the perceptual impact of new media, composed amidst the tumult of the real-world happenings of the 60s, argues for the participatory, multi-layered sensuous address of television, one that adds a tactile dimension to television's 'inclusive disjunction' of sound and image proposed by Deleuze: "The TV image requires each instant that we 'close' the spaces in the mesh by a convulsive sensuous participation that is profoundly kinetic and tactile, because tactility is the interplay of the senses, rather than the isolated contact of skin and 
object" (McLuhan 2003: 419). It is then both television's capacity to contain, preserve and transmit the heterogeneous activities that cannot be theorised as having a coherent whole, as well as the instantaneity of its muti-layered mode of sensory address, that artists in this period such as Serra, Nauman, and indeed Beckett, turn towards television and video to proclaim, to paraphrase Rosalind Krauss, the end of object-centred medium specificity such that, in the age of television, we inhabit a postmedium condition.

Within such a context, it is perhaps only surprising for literary critics used to categorising Beckett as a canonical modernist writer and dramatist that at this moment, in 1968, he begins his first experiments in video, with sketches for a 'Film Vidéo-Casette projet 1968-1972' that prepare the way for his television works. It is evident that Beckett's experiments in television and video were part of the same experimental milieu as the poetics and performances of contemporaries like McClure and Kaprow (and Artaud's work would have been familiar to Beckett not least through their mutual connection to Jean-Louis Barrault). What interests me is how Beckett's television works engage with the specificities of the medium to make use of, and indeed refine and purify, the experimental techniques and features associated with suddenness as a mode of temporal appearance in ways that clear a space for the multimedia and video works whose production would follow. ${ }^{19}$

Take for example the television version of Not I, first broadcast on BBC 2 in 1973, which Beckett intended to work "on the nerves of the audience, not its intellect" (Gontarski 1999: xvii), recalling McLuhan's insistence on the "convulsive sensuous participation" and multisensory address of television, as well as Artaud's desire to turn spectators into sensitive vibratory bodies. This television work starring Billie Whitelaw consists of one, 15-minute close-up shot of a woman's mouth, and the audience's concentration must switch between the opaque material 'thisness' of the visual image -the raw material meatiness of moving lips and tongue - and the flow of almost unintelligible discourse issuing from the mouth. Mouth's flow of words at times seems to metabolise the energies of mechanical media through the materiality of language to disrupt the continuum of 'her' (Mouth's) story, as she interrupts her narrative with references to "a sudden flash.......] more likely the machine" or with the sudden production of embodied, feminized screams that recall Artaud's Pour en finir avec le jugement de Dieu, combined with Kaprow-esque directives to listen: "no screaming for help for example... should she feel so inclined... scream... [Screams.]... then listen.... [Silence].... scream again... [Screams again] ... then listen again. ... [Silence]" (Beckett 1984: 218). ${ }^{20}$

This media file cannot be displayed. Please refer to the online document http:// journals.openedition.org/angles/4797

41 Such sudden eruptions that work on the nerves, not only the intellect, of its audience are a prominent feature of Bruce Nauman's Raw Materials, an installation in the vast tunnel of the Tate Modern's Turbine Hall, a correlative of Beckett's visual image of mouth given sculptural opacity and volume, all the meaty organicism of Mouth enlarged and frozen into concrete and metal by the Medusa's stare of industrialisation. Here, the energies of mechanical media are used to disrupt the continuum of 'his' (Nauman's) own story, as fragments of raw material of Nauman's own past career (audio tracts from videos, installations, and texts belonging to Nauman's sculptures, drawings, prints) are metabolised through mechanical mouth of the loudspeakers that 
issue sudden high-frequency shouts and screams that hit the passing audience, disrupt the continuity of their passage, and offer a spectral trace that touches us with the vibrations of the artist's own material past, echoing within the structure of the Turbine Hall's industrial past.

As we pass through the hall, the sudden shouts and screams are most frequently not perceived as articulate language (unless one can bear to stand still), but as attacks that quite literally hit us and penetrate our body with the arrival of a sonorous presence that flashes or flits by as they propel our movement onward (see first excerpt starting at 4'15", and second excerpt starting at 4'55").

This media file cannot be displayed. Please refer to the online document http:// journals.openedition.org/angles/4797

The mechanical repetitions of the shout 'work, work, work' in the second excerpt can not only be heard as self-directives to Nauman's own past productivity. They also mark the vestigial presence of a moment from the Turbine's hall own industrial past as part of Bankside Powerstation, and London electricity substation, condensed into a sonorous mass that hits us both physically and mentally in ways that, at the moment of its appearance at least, cannot be assimilated by consciousness into the unfolding teleology of lived experience. Our movement through this space is thus not only conditioned by the vestigial presence of industrial modernity. The perceptual experience often reproduces the shock experience of that past in all its immediacy: the sudden attack of sonorous presence issuing from one of the 18 different loudspeakers momentarily hits us and disrupts our passage before propelling us onward with all the disorienting demands of progress.

The sudden emergence and disappearance of presences from the past is actualised most profoundly in the audio-visual kinetic address of the television medium in Beckett's Ghost Trio, where, as in McLure's Ghost Tantras, spectral presences reach out and touch us like "the touch of velvet on fingertips [that] may become a cry when time is stopped." Beckett's Ghost Trio offers the visual image of a listening figure enclosed in a room, like a solitary, purified, Kaprow environment turned into a sensory deprivation experiment, where, between long silences when nothing happens, spectral presences emerge and disappear of their own accord. The most prominent and most substantial among these, as we mentioned earlier, are fragments of Beethoven's 'The Ghost.' These short, 5 to 10-second fragments that emerge and disappear at least six times are played in random order, not in sequence, and Beckett invariably omits the first bar of the section that appears. This disrupts and smooths out the continuity of melodic development, so that the fragments of Beethoven's music are perceived as sonic masses that appear to float, suspended, vibrating in empty space. The emergence of the music, however slow it may seem, with the piano's short attack, long decay, and fast release, nevertheless appears as a sudden quickening in relation to the emptiness of the rest of the work.

This media file cannot be displayed. Please refer to the online document http:// journals.openedition.org/angles/4797

It is as though the Benjaminian flash that arrests the continuum of time were transposed into the spectral, sonorous mass of music that, for the momentary duration 
of its appearance, interrupts the endless passage of time and overlays the flattened grey-scale visual image on the screen with a colour and texture that reaches out to touch us with the caress of spectral beauty from another world. In this regard, it is the inverse of the haunting final visual image of the play, a close-up of the heretofore unseen listener's face, one that shocks and fascinates, drawing us towards it like the touch of one of Harry Potter's Dementors, against whose powers we have only the fading presence of the music to shield us. But no sooner do we reach out to try to grasp and hold on to that ghostly musical presence, than it is already gone.

Finally, Beckett's Quad is a work that perhaps most fully engages with the 'profoundly kinetic and tactile' properties of the television medium. The work's title itself recalls the Quadrature Amplitude Modifications used in television broadcast transmissions. It features four figures, each enveloped in a different monochrome gown whose white, yellow, blue and red colours suggest the colour encoding system for analogue television used in the United Kingdom on BBC 2 and in West Germany, where Quad was first broadcast. $^{21}$

This media file cannot be displayed. Please refer to the online document http:// journals.openedition.org/angles/4797

As these figures each follow their particular course along the sides and diagonals of a square, their pacing marked by the sound of percussive sound-effects and footfalls, they appear not so much as characters, but as vectors for forces beyond their control, propelled by spectral, mechanical forces. It is as though the horizontal technological force that launched Futurism with a sudden car crash were metabolised through their hunched-over, aging, organic earth-bound bodies. When the figures' movements bring them together near the 'danger zone' at the centre of the square, they suddenly veer to avoid the anticipated impact of collision, as though the sudden emergence of the crash indexing technological modernity and the ensuing destruction of two world wars were held at bay, a happening that fails to happen.

If the title of Harrison and Wood's exhibition of their video works, Unrelated Incidents, invokes, once again, those happenings that merely happen, these seem to be born by going backwards through a space cleared by Beckett's previous work. In their highly kinetic and tactile, minutely choreographed video performances, the bodies of the two performers and other material things move through their courses within, on or around intricately constructed geometric forms. The two artists' performances not only metabolise the tragic-comic circus-act duos of Beckett's early dramatic performances (Didi and Gogo of Godot, Hamm and Clov of Endgame), and the stone-faced demeanour of Buster Keaton in Beckett's Film. In their works, the horizontal technological force of modernity is naturalised as vertical gravitational force, where, between long silences when nothing happens, the unstable equilibrium balancing the movements of bodies and things in relation to the material support of constructed forms is suddenly derailed, with the resonant crash, thunk or plop of bodies falling to the ground. One might say that their work actualises the anticipated crash that never appeared in Beckett's Quad, marking the natural end-point where the propulsive forces of modernity come to a rest.

Here are a few excerpts, the first from the series entitled Device (1996), and the second from the aptly titled series, 26 Drawing and Falling Things (2001). 
This media file cannot be displayed. Please refer to the online document http:// journals.openedition.org/angles/4797

This media file cannot be displayed. Please refer to the online document http:// journals.openedition.org/angles/4797 inexplicable, happening of an event that emerges and disappears - whether appearing as the explosive 'attack' of technological violence, or in the guise of the organic, almost tactile immediacy of an embodied scream, as the crash of bodily impact, or as the soft touch of affective vibrations, of spectral whispers and shadows - involves exposure to exteriority and contingency that cannot be indexed to the causal unfolding of events directed by the teleological demands of story-telling or of history. In addition to disrupting traditional aesthetic forms and conceptions of historical progress, the aesthetic disposition associated with this mode of appearing also disrupts the audience's usual disposition of interpretive mastery in regards to events, as here we are subject to, rather than master of, appearances that happen, and can be momentarily touched or moved by an audio visual kinaesthetic presence, with no knowledge of its origins and no directions as to the consequences of what follows. The disposition implied by this mode of appearing brings to the fore the idea that subjectivity is not a fundamental, autonomous, fixed, cogito, but what Peter Sloterdijk calls a medium percussum, subject to being moved and shaken by presences and vibrations exterior to the self (2017: 38). Or as Beckett wrote, "I'm in the middle [...] Perhaps that what I feel, myself vibrating, I'm the tympanum, on the one hand the mind, the other the world, I don't belong to either" (Beckett 1979: 353).

\section{Listening}

«Curieux combien on est acculé au mot

"écouter," nous qui ne sommes tout de même pas

des auditifs »

Samuel Beckett, letter to Georges Duthuit (Craig

The disposition of listening features prominently in descriptions of the multi-layered modes of audience address associated with both modes of temporal appearing, whether the enduring passing away marked by murmur and hum, or suddenness marked by 
shout and crash. These features, as well as the disposition of listening, emerge further to the foreground of appearances as we move from the age of mechanical reproduction of Benjamin and Beckett through our present, $21^{\text {st }}$-century modernity, and its proliferation of electronic media. This does not mean, that, against traditional modes of audience address bound up in the presumed 'opticality' of print media, the age of mechanical reproduction inaugurates, as Jean Richard Bloch announced in a 1930 letter to Artaud, "With talking machines wireless, sound movies, the ear will take its revenge" against the eye (Hollier 1997: 27). Or, as McLuhan and Walter J. Ong prophesied in the late 60s, that the age of new electronic media brings about a new age of "secondary orality" (or aurality)..$^{22}$ It is rather that, from the age of mechanical reproduction to our own new electronic modernity, the increasing proliferation of multimedia images associated with the oft-proclaimed dominance of visual culture (or the society of the spectacle), counter-intuitively play a role in overcoming the dominance of visual paradigms in conceptual thought and as a mode of sensory address, by pushing those paradigms to their historical limit. As Peter Sloterdijk suggests, "It may be symptomatic [of our modernity] that the inflation of media images has tended towards a maximum beyond which the absolutism of seeing can no longer be sustained" (2017: 39). This overturning of the absolutism of seeing - associated with stable subjects' interpretive mastery of stable objects of perception - results in the increasing turn of contemporary thought towards listening as a paradigmatic mode of aesthetic perception, one capable of attending to the multi-layered sensory address of contemporary art and multimedia by moving with, or oscillating between, auditory, tactile and kinaesthetic registers. As Jean-Luc Nancy, a thinker whose work attends to the multiplicity of arts, from the portraits of the past to the audio-video installations of the contemporary art scene, writes:
Par différence avec la vision d'un objet, la saisie de l'image [...] représenterait une vision opérant à la manière d'une ouïe: une vision qui éprouverait dans la vue (la veduta, le Bild, le tableau) le mouvement de sa levée en moi et de son retour vers moi. Eprouvant ainsi sa résonance l'image formerait la sonorité d'une vision, et l'art de l'image une musique de la vue. Ou bien encore une danse, si la danse constitue dans l'ordre du corps en tant que tel un mouvement semblable de mise en résonance. (Nancy $2011: 77$ )

I'd like now to invite you to 'listen with your eyes' (to recall the title of one recent installation by Maurizio Nannucci) ${ }^{23}$ to one final video extract from The Only Other Point, a work created by Harrison and Wood (2005). This presents us with a staging of what Nancy calls the resonance of the image, the sonority of vision or the musical dance of sight, as a silent playing out of the music of the spheres, of balls suspended, rotating in space, and the enduring passing away of bubbles falling.

This media file cannot be displayed. Please refer to the online document http:// journals.openedition.org/angles/4797

Despite the apparent difference of these works across television, video, film, installation, or performance, the appearance of phenomena associated with the passing resonance of murmurs and hums, or the sudden appearance of shouts and crashes, are not minor side-effects or bugs in the operating systems of $20^{\text {th }}$ and $21^{\text {st }}$-century avantgarde art. Rather, they are fundamental features of these works. They produce perceptual experiences that momentarily suspend our distinguishing capacities, whether that of discrete, graspable objects or of teleological representations of time. 
Here, we can be at one with the enduring passing away of presences of the past, and with our own embodied present, at one and the same time. The pleasures and anxieties bound up in the perception of these works would then have to do with this spatiotemporal disorientation: for the duration of the experience, we are subjected to a process where we no longer orient ourselves according to recognizable frames of reference, but where we can nonetheless perceive with the greatest intensity. In other words, the wonder and pleasure of Beckett's work, as of those of his $21^{\text {st }}$-century contemporaries, is that they incite us to ask 'what's happening' without ever being able to identify, narrate, or explain definitively what happened.

\section{BIBLIOGRAPHY}

\section{Bibliography}

Adorno, Theodor W. "In Memory of Eichendorff." In Notes to Literature I. Ed. Rolf Tiedemann. Trans. Shierry Weber Nicholsen. New York: Columbia UP, 1991. 55-79.

Albright, Daniel. Beckett and Aesthetics. Cambridge UP, 2003.

Artaud, Antonin. “En finir avec les chefs-d'œuvre.” In Le Théâtre et son double. Paris: Gallimard, 1938. 79-89.

Artaud, Antonin. “No More Masterpieces.” Evergreen Review 2 (5), 1958: 150-9.

Ball, Steven. "Beyond the Cringe: Australia, Britain, and the Post-Colonial Film Avant-Garde." Senses of Cinema 78(3) 2016. https://www.sensesofcinema.com/2016/british-experimental/postcolonial-film-avant-garde/

Barthes, Roland. Le bruissement de la langue. Essais Critique IV. Paris : Editions de Seuil, 1984.

Beckett, Samuel. The Beckett Trilogy. London: Picador, 1979.

Beckett, Samuel. “German Letter of 1937 to Axel Kaun.” In Disjecta. Ed. Ruby Cohn. New York: Grove Press, 1984: 51-54.

Beckett, Samuel. The Collected Shorter Plays of Samuel Beckett. New York: Grove Press, 1984.

Beckett, Samuel. Quad et autres pièces pour la télévision. Trans. Edith Fournier. Suivi de Gilles Deleuze, L'Épuisé. Paris: Les Éditions de Minuit, 1992.

Benjamin, Walter. "The Work of Art in the Age of Mechanical Reproduction" (1936). Illuminations. Ed. Hannah Arendt. Trans. Harry Zohn. New York: Schocken Books, 1968a. 217-252.

Benjamin, Walter. "Theses on the Philosophy of History" (1940). Illuminations. Ed. Hannah Arendt. Trans. Harry Zohn. New York: Schocken Books, 1968b. 253-264.

Beugnet, Martine. "Introduction." In Indefinite Visions: Cinema and the Attractions of Uncertainty. Eds. Martine Beugnet, Allan Cameron, and Arild Fetveit. Edinburgh: Edinburgh UP, 2017. 1-13. DOI: 10.3366/edinburgh/9781474407120.003.0001 
Bignell, Jonathan. "Beyond the Fourth Wall: Experiments in TV Drama: Samuel Beckett's Plays on BBC TV.” 2 December 2012. http://blogs.reading.ac.uk/spaces-of-television/2012/12/02/beckettplays-on-bbc-tv/

Bohrer, Karl-Heinz. Suddenness: On the Moment of Aesthetic Appearance. Trans. Ruth Crowley. New York: Columbia UP, 1994.

Brater, Enoch. “Toward a Poetics of Television Technology: Beckett's Nacht und Träume and Quad." Modern Drama 28(1) 1985: 48-54. DOI: 10.1353/mdr.1985.0008

Cardwell, Sarah. Adaptation Revisited. Manchester: Manchester UP, 2002.

Cavell, Stanley. “The Fact of Television.” Daedalus 111 (4) 1982: 75-96.

Connor, Steven. "Shifting Ground"/ "Auf den schwankendem Boden." Exhibition catalogue Samuel Beckett, Bruce Nauman. Vienna: Kunsthalle Wien, 2000. 80-7.

Craig, George. Writing Beckett Letters. Cahiers 16. Paris: Sylph Editions, 2011.

Doane, Mary Ann. The Emergence of Cinematic Time: Modernity, Contingency, The Archive. Cambridge: Harvard UP, 2002.

Deleuze, Gilles. “L'Épuisé.” In Samuel Beckett, Quad et autres pièces pour la télévision. Paris: Les Éditions de Minuit, 1992. 55-106.

Ginsberg, Allen. "Howl." The Evergreen Review 1 (2) 1957: 137-147.

Glass, Loren. Grove Press, the Evergreen Review, and the Incorporation of the Avant-Garde (Post*45). Stanford: Stanford UP, 2013.

Gontarski, S. E., ed. The Theatrical Notebooks of Samuel Beckett: The Shorter Plays. New York: Faber \& Faber, 1999.

Gumbrecht, Hans Ulrich. After 1945: Latency as Origin of the Present. Stanford: Stanford UP, 2013.

Harari, Dror. “'Breath' and the Tradition of 1960s New Realism: Between Theatre and Art." Samuel Beckett Today / Aujourd'hui, 22, 2010: 423-433. https://www.jstor.org/stable/25781940

Hollier, Denis. “Artaud's Sound Sytem.” October (80) 1997: 27-37.

Husserl, Edmund. The Phenomenology of Internal Time-consciousness (1928). Ed. Martin Heidegger. Trans. James S. Churchill. Bloomington: Indiana UP, 2019.

Janus, Adrienne. "Funny Walks.” The Vacuum (Beckett Centenary Festival). Centenary Edition. Published by Factotum. 54: 2012a.

Janus, Adrienne. Gravity Light. The Hague: Gallery West, 2012b. https://www.westdenhaag.nl/ publications/Harrison_and_Wood/unrelated_incidents

Kaprow, Allan. “The Happenings Are Dead! Long live the Happenings!” (1966). The Blurring of Art and Life. Ed. Jeff Kelley. Berkeley: U. California P., 2003. 59-65.

Kahn, Douglas. Noise, Water, Meat: A History of Sound in the Arts. London and Cambridge: The MIT Press, 1999.

Kittler, Friedrich. “Introduction.” Gramophone, Film, Typewriter. Stanford: Stanford UP, 1999. 1-19.

Krauss, Rosalind. A Voyage on the North Sea: Art in the Age of the Post-Medium Condition. London: Thames and Hudson, 1999. 
Lewis, Wyndham. Ed. "Manifesto I" Blast No. 1: Review of the Great English Vortex. London: John Lane, the Bodley Head, June 20, 1914: 11-28. https://www.tate.org.uk/art/art-terms/v/vorticism/ blast-radical-vorticist-manifesto

Marinetti, F.T. "The Founding and Manifesto of Futurism" Front Page, Le Figaro (20 February 1909). https://ubu.com/papers/marinetti_futurist-manifesto.html

Mercier, Vivian. “The Uneventful Event.” The Irish Times (18 February 1956). In Critical Essays on Samuel Beckett. Ed. Lance St. John Butler. Aldershot: Ashgate, 1993. 29-30.

McClure, Michael. “The Growl.” Evergreen Review 8.32 (April-May 1964): 75-89.

McClure, Michael. Ghost Tantras [1964]. San Francisco: City Lights, 2013.

McLuhan, Marshall. The Gutenberg Galaxy. Toronto: U. of Toronto P., 1962.

McLuhan, Marshall. Understanding Media: The Extensions of Man [1964]. New York: McGraw Hill, 2003.

McLuhan, Marshall. “Innovation is Obsolete,” Evergreen Review 15.90 (June 1971): 48-64.

Nancy, Jean Luc. “L'image: mimesis \& methexis.” In Penser l'image. Ed. Emmanuel Alloa. Paris: Les presses du réel, 2011. 69-80.

Nixon, Mark. "Beckett's Unpublished Canon." In The Edinburgh Companion to Samuel Beckett and the Arts. Ed. S.E. Gontarski. Edinburgh UP, 2014. 282-305.

Ong, Walter J. Orality and Literacy: Technologizing the Word. New York: Methuen, 1982.

Perloff, Marjorie. 21st Century Modernism: The New Poetics. Oxford: Blackwell, 2002.

Reginio, Robert, David Houston Jones, and Katherine Weiss, eds. Samuel Beckett and Contemporary Art. New York: Columbia UP, 2017.

Russolo, Luigi. The Art of Noise : Futurist Manifesto [1913]. New York: Something Else Press, 1967.

Seel, Martin. The Aesthetics of Appearing. Stanford: Stanford UP, 2005.

Sloterdijk, Peter. "Where are we when we hear music?" In The Aesthetic Imperative: Writings on Art. Peter Sloterdijk. Ed. Peter Weibel. Trans. Karen Margolis. Cambridge: Polity Press, 2017. 27-45.

Serres, Michel. Hermes I: La communication. Paris: Les Éditions de minuit, 1968.

Serres, Michel. Hermes II: L'interférence. Paris: Les Éditions de minuit, 1972.

Serres, Michel. Le parasite. Paris: Grasset, 1980.

Tubridy, Derval. "Beckett and Sonic Art.” In Samuel Beckett and Contemporary Art. Eds. Robert Reginio, David Houston Jones, and Katherine Weiss. New York: Columbia UP, 2017. 265-290.

Van Hulle, Dirk. “The Urge to Tell: Samuel Beckett's Not I as a Texte Brisé for Television.” Journal of Beckett Studies. 18 (1-2) 2009: 44-56. DOI: 10.3366/E0309520709000260

\section{Video and Film}

Beckett, Samuel. “Ghost Trio.” 21'. BBC 2. April 1977. https://www.youtube.com/watch? $\mathrm{v}=3 \mathrm{mtbEcwJUZI}$

Beckett, Samuel. “Quadrat I / II” 13'25”. Süddeutscher Rundfunk, 1981. https:// www.youtube.com/watch?v=4ZDRfnICq9M

Beckett, Samuel. “Not I.” 15mn. BBC 2. 1973. https://www.youtube.com/watch?v=M4LDwfKxr-M 
D’Arcy, John (sound design) \& Boyd, Cathy (Installation Director). Beckett Basement. Installation. Happy Days International Beckett Festival, Enniskillen, Ireland 23-27, August. 2012. Jonathan Frazer (Film). Clarecom Productions, 2012.

Harrison, Paul, and John Wood. Device. 2'45”. Beta, Single channel, 4:3. 1996. https:// www.ntticc.or.jp/en/archive/works/device/

Harrison, Paul, and John Wood. Twenty-Six (Drawing and Falling Things). 26-channel digital video installation, HD, 21'59". 2001. https://www.cristintierney.com/artists/39-john-wood-and-paulharrison/works/6942-john-wood-and-paul-harrison-twenty-six-drawing-and-fallingthings-2001/

Harrison, Paul, and John Wood. The Only Other Point. 13'44". Colour HD, Stereo. 2005. https:// lux.org.uk/work/the-only-other-point

Harrison, Paul, and John Wood. Unrelated Incidents. 1 March 2008. https://www.tate.org.uk/art/ artists/paul-harrison-7049/harrison-and-wood-studio-visit

Harrison, Paul, and John Wood. Night and Day. 24'18", Video HD, Edition 5/5. Acquisition by Lab'Bel in 2010. 2009. https://www.lab-bel.com/exhibition/night-and-day-2/

Harrison, Paul, and John Wood. "Bored Astronauts on the Moon". Single-channel HD video, 20'. 2012. https://www.westdenhaag.nl/exhibitions/12_10_Harrison_and_Wood/more6

Nauman, Bruce. "Raw Materials.” 2005. https://www.youtube.com/watch?v=vA2SUjTmCR0

Serra, Richard. “Hand Catching Lead.” 1968. https://www.youtube.com/watch?v=v-FJKI1lzt0

\section{NOTES}

1. In the genealogy of experimental poetics running from the 1930s to the 1980s, Marjorie Perloff situates Beckett between the 1930s Objectivist poets, mid-century New York School poets such as Frank O'Hara, and 1950s Frankfurt School Theorists such as Theodor Adorno: “Language poetry, together with its related 'experimental' or 'innovative' or 'alternative' poetries in the US and other Anglophone nations, has often been linked to [...] Gertrude Stein and Wittgenstein, to Guillaume Apollinaire and William Carlos Williams, the Objectivists and New York poets, Samuel Beckett, the Frankfurt School, and French poststructuralist theory." (Perloff: 1).

2. On the role of the Evergreen Review in fostering the transatlantic avant-garde, see Glass (2013).

3. "The satellite environment has transformed the planet itself into an art form. The total scrapping of the old Nature, and the planet itself, has created a garbage apocalypse." (McLuhan 1971:48).

4. "Happenings are today's only underground avant-garde. The End of the Happenings has been announced regularly since 1958." (Kaprow 1966/2003: 59)

5. On funny walks and gravitational instability in the works of Beckett and Nauman, see Connor (2000) and Janus (2012a).

6. On Beckett's experiments in video, Mark Nixon writes that Beckett's 'Film Vidéo-Cassette projet' 1968-1972 “anticipates later TV plays such as Ghost Trio. [...] What is most striking about Beckett's sketch is his envisaged creative use of the video medium, which was in 1972 a relatively new technology, though the professional sector and television networks had been using it since the mid-1960s" (Nixon 2014: 295-6). 
7. Jonathan Bignell describes Beckett's work in television as "visually distinctive plays, worthy of the term 'experimental,' and the story of how they were made and received reveals fascinating relationships between Beckett, the BBC and different groups of viewers" (Bignell 2021).

8. The expression "modes of appearing" belongs to the phenomenological tradition that runs from Husserl's 1905 lectures on The Phenomenology of Internal Timeconsciousness (1928), one of which was entitled "Imminent Temporal Objects and their Modes of Appearance," through Karl-Heinz Bohrer's Suddenness: On the Moment of Aesthetic Appearance (1994) and Martin Seel's Aesthetics of Appearing (2005). If as Husserl claims, "Every temporal being appears in one or another continually changing mode," then the question of "what is involved in this appearing" involves qualitative descriptions of our perceptual experiences, rather than quantitative indicators of temporal units or representations such as past, present, future (Husserl 2019: 47, 36). In the midst of their appearing to us, for example, things and events may be perceived as occurring suddenly (even if they happen relatively slowly) or as both enduring and continually passing away.

9. "One of the important themes of Beckett's later career is the hunt for new media to stimulate his extremely media-driven artistic imagination. [...] All media, to Beckett's way of thinking, are mutilated and inept; but the technological media of the twentieth century confess their incompetences in especially striking ways" (Albright 2003: 6).

10. Krauss directly links artists' experiments with television and video to the end of objectcentred, medium specific conceptions of art and the emergence of the post-medium condition of $21^{\text {st }}$-century multi-media installation and video performance art: “[...] even if video had a distinct technical support - its own apparatus, so to speak - it occupied a kind of discursive chaos, a heterogeneity of activities that could not be theorized as coherent or conceived of as having something like an essence or unifying core. [...] it proclaimed the end of medium-specificity. In the age of television, so it broadcast, we inhabit a post-medium condition" (Krauss 1999: 31-2).

11. McLure's Ghost Tantras (1962) is a collection of poems recorded in part on audio-tape and film while the poet read to lions at the zoo. Kaprow's Happenings not only frequently used literary texts, audio, video projection in the live performances, but existed then as now as works instantiated across these media.

12. On the distinction between 'provincial' or peripheral and 'central' or cosmopolitan avantgardes, see Ball, Steven, 2016.

13. Derval Tubridy's "Beckett and Sonic Art," treats Beckett's inter-medial work as a vital force for contemporary artists, with specific reference to John D'Arcy's and Cathie Boyd's installation Beckett Basement (Tubridy, 2017).

14. This back-and-forth movement of the enduring passing away of appearances, as applied to moving images, is also addressed by Martine Beugnet's recent book of the aesthetics of the indistinct in cinema, in her attention to wave phenomena as a prominent feature of early cinema. Her introduction implicitly acknowledges the fundamental inter-mediality of these phenomena, moving from a discussion of Etienne Jules Marey's first chronophotographic film of $1891 \mathrm{La}$ Vague, to Georges Didi-Huberman's poetics of the wave in literary creation as the "very manifestation of incessant motion and constant transformation, [that] can only be grasped fleetingly" (Beugnet 2017: 3).

15. In television "what is present to us is not the world, but an event standing out from the world. Its point is not to reveal, but to cover (as with a gun), to keep something on view. [...] Taking this tip, I will characterize the material basis of television as a current of simultaneous event reception" (Cavell 1982: 85).

16. "Television viewers, even more than film audiences, perceive television as made up of a series of separate images that can be captured and held. [With the ability to manipulate video 
recordings of television] The television images themselves, far from being understood as 'present,' become detached from their regular temporal flow, and take on a more uncertain temporality: they appear 'tenseless"' (Cardwell 2002: 84).

17. I use the term noise here not as a merely auditory phenomenon, but as a disturbance to meaning-constitution in systems of communication and representation, as it is used in the systems and information theory that informs the work of media theorists such as Friedrich Kittler and philosophers of science such as Michel Serres, where noise indicates interference, the 'bruit parasite' that both constitutes and disrupts systemic communication. See Kittler (1999) and Serres $(1968,1972,1980)$.

18. On the scream as a feature of experimental and avant-garde poetics, particularly in relation to Artaud's reception in the post-war American context, see Kahn (1999).

19. Scholars in the field of Beckett Studies tend to treat his works for television as texts, even as they acknowledge Beckett's television works as being specifically designed for that medium. Enoch Brater, in describing Beckett's television works declares, for example, "There is, however, a performance, one, moreover, which is meant to be regularised and fixed forever on videotape. The performance we see on television is the text" (Brater 1985: 53). See also Dirk Van Hulle (2009).

20. Not $I$, the television work starring Billie Whitelaw, was broadcast under the title Shades alongside Ghost Trio, ...but the clouds... as part of the BBC 2 Lively Arts series.

21. Quad was first transmitted by BBC 2 in December, 1982 and in Germany by Süddeutscher Rundfunk in 1981.

22. Ong defines secondary orality as the orality "of present-day high-technology culture, in which a new orality is sustained by telephone, radio, television and other electronic devices that depend for their existence and functioning on writing and print." (Ong 1982: 11) McLuhan argues that electronic media's perceptual effects extend the audio-tactile modes of sensory address of oral cultures to create a global village: "electronic media extends non-linear, holistic perception characteristic of oral cultures to the globe" (McLuhan 1962).

23. Maurizio Nannucci, Listen with Your Eyes, light installation projected from the roof of the Centre national des arts plastiques Paris, 2010 / Centre de Création Contemporaine Olivier Debray, Tours, 2018.

\section{ABSTRACTS}

The murmurs, hums, shouts, and crashes explored in this paper are not merely sound effects. They are fundamental material in the avant-garde attack on the traditional work of art as a distinct object of interpretation and exposition. They are thus instrumental in producing the experimental forms and temporalities of what Rosalind Krauss calls the 'post-medium' condition of late $20^{\text {th }}$ century and early $21^{\text {st }}$ century multi-media installation and video performance art. Moving from Beckett's late television plays (Ghost Trio, 1975) to contemporary installation and video art of central and peripheral avant-gardes such as Bruce Nauman's Raw Materials (Tate Modern, 2004), John d'Arcy's Beckett's Basement (Castle Coole, 2011), and Harrison and Wood's video performance Unrelated Incidents (Gallery Den Haag, 2012), this paper explores how murmurs, hums, shouts and crashes index two temporal phenomena brought to the fore by $20^{\text {th }}$ and $21^{\text {st }}$ century experimentation whose ephemeral, ungraspable nature demands a kind of perception more akin to listening than to looking. The first has to do with the lingering 
resonance of a continuously passing audio-visual movement - the indistinct murmuring, organic or mechanical rustling, humming and shimmering that are particular features of Beckett's work and phenomena fundamental to contemporary aesthetic practice. The second has to do with the sudden, inexplicable appearing of an audio-visual presence - the shouts, crashes, flashes and other momentary events associated as much with the Benjaminian shock of the modern as with the instantaneity of contemporary performance. The wonder and pleasure of Beckett's work, as of those of his $21^{\text {st }}$-century contemporaries, is that they incite us to ask 'what's happening' without ever being able to identify, narrate, or explain definitively what happened.

Les murmures, les bourdonnements, les cris et les chocs étudiés dans cet article ne sont pas de simples effets sonores. Ils constituent un matériau fondamental dans les attaques de l'avantgarde contre l'œuvre d'art traditionnelle en tant qu'objet distinct d'interprétation et de représentation. Ils contribuent ainsi à produire les formes et les temporalités expérimentales de ce que Rosalind Krauss appelle la condition "post-médium » de l'installation multimédia et de l'art de la performance vidéo de la fin du XX ${ }^{e}$ siècle et du début du XXI ${ }^{\mathrm{e}}$ siècle. En allant des pièces télévisées de la dernière période de Beckett (Ghost Trio, 1975) à l'installation contemporaine et à l'art vidéo des avant-gardes principales et marginales telles que Raw Materials de Bruce Nauman (Tate Modern, 2004), Beckett's Basement de John d'Arcy (Castle Coole, 2011), et la performance vidéo Unrelated Incidents de Harrison et Wood (Galerie Den Haag, 2012), cet article explore comment les murmures, les bourdonnements, les cris et les chocs mettent en évidence deux modes d'apparition temporelle mis en avant par l'expérimentation des $\mathrm{XX}^{\mathrm{e}}$ et XXI $\mathrm{XI}^{\mathrm{e}}$ siècles, dont la nature éphémère et insaisissable exige un type de perception plus proche de l'écoute que du regard. Le premier a trait à la résonance persistante d'un mouvement audiovisuel qui continue sans cesse - le murmure indistinct, le bruissement organique ou mécanique, le bourdonnement et le chatoiement qui sont des caractéristiques particulières de l'œuvre de Beckett et des phénomènes essentiels à la pratique esthétique contemporaine. La seconde a trait à l'apparition soudaine et inexplicable d'une présence audiovisuelle - les cris, les fracas, les flashs et autres événements fugaces associés aussi bien au choc benjaminien de la modernité qu'à l'instantanéité de la performance contemporaine. La merveille et le plaisir de l'œuvre de Beckett, comme de celles de ses contemporains du XXI ${ }^{\mathrm{e}}$ siècle, est qu'elles nous incitent à nous demander «ce qui se passe» sans jamais pouvoir identifier, raconter ou expliquer définitivement ce qui s'est passé.

\section{INDEX}

Mots-clés: Beckett Samuel, Nauman Bruce, D’Arcy John, Harrison Paul, Wood John, installation multimédia, performance art vidéo, avant-garde, post-medium, art

Keywords: Beckett Samuel, Nauman Bruce, D’Arcy John, Harrison Paul, Wood John, multi-media installation, video performance art, avant-garde, post-medium, art

\section{AUTHOR}

\section{ADRIENNE JANUS}

Associate Professor/Maître de Conférences in English and Theatre at the University of Tours, France, Adrienne Janus works across the areas of literature and audio-visual culture, theatre and performance studies. Her publications include works on Jean-Luc Nancy and visual culture (Edinburgh UP, 2016), the turn towards listening in continental philosophy (Comparative Literature, Duke UP, 2011) and laughter, murmurs and music in the works of Yeats, Joyce and 
Beckett (Journal of Modern Literature, John Hopkins UP, 2009). From 2006-2016, she was Associate Professor (Lecturer) in the School of English, Music, Film and Visual Culture at the University of Aberdeen, and prior to this, held post-doctoral positions in the French and Humanities departments at Stanford University and at the Institute of Irish Studies at Queens University, Belfast. Contact: Adrienne.janus [at] univ-tours.fr 